\title{
Existential Chaos: A Critique of Catherine Keller's Position Towards Creation and Divine Omnipotence
}

\begin{abstract}
The two dominant concepts Catherine Keller examines in her study of creatio ex profundis, creation out of chaos, are the feminine tehomic language and refutation of divine omnipotence. She studies both these concepts through a feminist lens as well as with an overarching question as to why creatio ex nihilo, creation from nothing, has commandeered the thought behind Genesis exegesis and creation theology. Using various literary styles, both religious and secular, Keller attempts to deconstruct creation out of nothing and argue how a theology of becoming is more appropriate given the language of Genesis and creation as a whole. Rather than merely substitute the present masculine understandings of God and creation with the feminine, she persuades for a return to the foundation of tehomic language in an effort to reconstruct the negative feminine connotations of chaos and support a theology of becoming without a "divine dominology." The purpose of this paper is to offer an examination of Keller's text and counterarguments to her understanding of creatio ex nihilo and ex profundis. There are various examples of male dominant thought in theology throughout history; however, divine omnipotence, both in general and as associated with creation theology, is not an affront to the feminine and creatio ex profundis. Keller's fault does not lie in the notion of creatio ex profundis and its validity; rather, her argument concerning the domineering power of divine omnipotence and its association with creatio ex nihilo remains insufficient.
\end{abstract}

\section{Introduction}

In her exploration of creation theology, Catherine Keller provides one the most comprehensive illustrations of creatio ex profundis, creation from the primal chaos, and Genesis. While part of her effort is to elucidate the exegetical meaning of the Genesis creation narrative, Keller also provocatively confronts the accepted notion of creatio ex nihilo, calling such a doctrine patriarchal and controlling of the feminine waters. She continues further and disputes the understanding of divine omnipotence, viewing the image of God as correlative to the doctrine of ex nihilo. Following a similar plan, Keller perceives omnipotence as an illustration of domineering power and in direct conflict with the chaotic depths of creation. The main priority of this critique is to examine Keller's text and provide counterarguments to her presentation of 
creatio ex nihilo and ex profundis, specifically her use of tehom, the chaotic waters of Genesis, and her rejection of God's omnipotence in relation to her criticism of ex nihilo. Keller views the two notions of omnipotence and creatio ex nihilo as mutually inclusive and, thus, an affront to the feminine. Referring to the work of Kathryn Tanner and Jon Levenson, I will propose a different approach to the interpretation of creation theology, one in which divine omnipotence remains appropriate for and respectful of both creatio ex nihilo and ex profundis.

\section{Keller's Approach to Genesis 1:1-2 and Creation Theology}

Keller challenges the traditional notion of creatio ex nihilo and proposes a close examination of the theology concerning creatio ex profundis. Her focus centers on the opening two verses of Genesis: "In the beginning when God created the heavens and the earth, the earth was a formless void and darkness covered the face of the deep, while a wind from God swept over the face of the waters." ${ }^{\prime \prime}$ In current theological studies, there are three main perspectives held toward the notion of creatio ex nihilo in relation to these two verses of Genesis. ${ }^{2}$ The first is the position held by Keller in that creatio ex nihilo is neither biblically based nor consistent with the faith tradition of the historical Judeo-Christian context. Rather, creation as forming out of nothing is an interpretation imposed upon what is described in the waters of Genesis. Keller and other critics of creatio ex nihilo proclaim such a notion is based on an avoidance of the chaos, which she perceives as an act of fear given the literary traditions surrounding the Psalms' use of Leviathan. ${ }^{3}$ The second perspective has a more neutral opinion of creatio ex nihilo. Those who

\footnotetext{
${ }^{1}$ All biblical references made in this paper are from The HarperCollins Study Bible, New Revised Standard Version, unless stated otherwise.

${ }^{2}$ Brian Robinette, "The Difference Nothing Makes: Creatio Ex Nihilo, Resurrection, and Divine Gratuity," Theological Studies 72 (2011): 527.

${ }^{3}$ In chapter 2, Keller claims the psalmist denounces the blessing of the sea monsters in Gen 1:21 and portrays the Lord as "crushing the heads of Leviathan," as stated in Psalm 74:14. She views such a vilification and perceived fear of chaos as a result of the literary traditions involving the divine battling against the chaotic beasts. These
} 
hold this perspective still view the notion of creation out of nothing as a developed belief not explicitly stemming from Genesis; however, unlike the position held by Keller, the notion is accepted as compatible with biblical tradition while also elucidating creation theology. Finally, the third perspective is similar to the second. This viewpoint accepts creatio ex nihilo as consistent with the description in Genesis as well as maintaining biblical tradition. Yet, in contrast to the previous position, the notion of ex nihilo is apparent and derived from the creation narrative. $^{4}$

The latter two viewpoints of creatio ex nihilo are the most accepted in present theological studies and practices, likely due to the established tradition from the early church fathers. In Gerhard May's examination of creatio ex nihilo, the beginning of the doctrine's formation developed from the theological studies of Tatian and Theophilus of Antioch as well as Irenaeus. ${ }^{5}$ Tatian used his teachings on the Logos in order to advance the concept of God as the creator of matter rather than creating from pre-existing chaos:

The Logos comes forth from God to order matter into the cosmos. The matter which the Logos shapes cannot, however, have been, like God, without a beginning, as in that case it would have to be thought of as a second, godlike principle, but it is brought into being by God himself. ${ }^{6}$

Although he does not address the beginnings of matter as "creation," Tatian provides an argument for God as originator of the matter and, eventually, as shaper of the world. Theophilis expands the teachings of Tatian by providing terminology specific to the developing doctrine of

traditions, according to Keller, allowed for a phobia of the chaotic waters of Genesis and the development of creatio ex nihilo. See Catherine Keller, The Face of the Deep, (New York: Routledge, 2003), xvi, 26-7.

${ }^{4}$ Robinette, 258.

${ }^{5}$ Gerhard May, Creatio Ex Nihilo: The Doctrine of 'Creation out of Nothing' in Early Christian Thought, (Edinburgh, T\&T Clark, 1994), 148.

${ }^{6}$ Ibid, 149. 
creatio ex nihilo. May explains the two important developments within Theophilis' writings: 'On the one hand with the significant statement that God creates 'out of nothing,' on the other hand with the thesis that the sovereign divine will is the sole ground of creation." ${ }^{, 7}$ Similarly, Irenaeus continues the notion of creatio ex nihilo, specifically God's free will in creation. He furthers the understanding of God's will in creation as belonging to His will to save. ${ }^{8}$ The current church doctrine on creation remains grounded in the teachings of these church fathers as well as other theologians. However, Keller raises issue with the still accepted tradition of creatio ex nihilo, which she finds as conflicting to the language of Genesis.

In order to understand the full complexity of the verses, she bases her argument on her own translation grounded in the original Hebrew language: "When in the beginning Elohim created the heaven and earth, the earth was tohu va bohu, darkness was upon the face of tehom, and the ruach elohim vibrating upon the face of the waters." She first illustrates what is understood by this tehom (chaos), mentioned in Genesis 1:2, as an effort to answer the question why tehom has lost its place in Christian creation theology. Based on the absence of tehom from present theology, she views such a misunderstanding, or perhaps even a deliberate dismissal, as harmful to the complexities of creation. Furthermore, Keller goes as far as to conclude the lack of tehomic language and the tradition of creatio ex nihilo are due to a fear of chaos. This fear only perpetuates the misconception surrounding the deep waters of creation while simultaneously feeding the fear, forming a cycle that will endure in western theology. ${ }^{10}$ Keller aims to return to the tehomic deep waters of Genesis to break this cycle and, even further, to challenge the presence of mastery in tradition.

\footnotetext{
${ }^{7}$ Ibid, 161.

${ }^{8}$ Ibid, 178.

${ }^{9}$ Keller, The Face of the Deep, xv.

${ }^{10}$ Ibid, xvi.
} 
Prior to addressing the notion of omnipotence perceived as God's dominating power, Keller explores the significance of tehom in relation to creation as well as how the doctrine of creatio ex nihilo is a detrimental perception of Genesis. Much of her understanding of tehom is based in a theology of becoming, which stems from process theology and describes God's creative expression in using the chaotic waters present in Genesis to form the infinite process of creation. According to Keller, a fully compiled theology of creatio ex profundis does not exist; however, Alfred North Whitehead's cosmography writings acknowledge openly the notion of ex profundis. The resulting process theology further develops the watery depths of creation, but only within the context of ecology, the natural creative state of creation, rather than a theology of creation and Genesis. ${ }^{11}$ In examining Whitehead's ecological view of God, ${ }^{12}$ Roland Faber states:

In this process of becoming concrete, God is that particular dipolar- "mental" and "physical" - event from which, on the one hand, every event acquires, as its beginning, the possibility of new becoming (the ideas of God's mental reality), and into which, on the other hand, every event happening that has become concrete is then taken up (the concrete world as God's physical reality)... While the world acquires creative form and deliverance in God, God, who happens as event Godself, gives Godself the world as possibility and takes it up as reality. ${ }^{13}$

This creative form of the universe is what allows itself to move from potentiality towards unity, continually undergoing a process of becoming. Whitehead then interpreted God's role as the one

\footnotetext{
${ }^{11}$ Ibid, 4.

${ }^{12}$ An ecological view of God emphasizes God's immanence in the world alongside the interconnected creativity of nature, which moves from a potentiality toward a teleological unity. With such an emphasis, the process of becoming is realized through creation and its relationship with God. See Roland Faber, God as Poet of the World: Exploring Process Theology, trans. Douglas W. Stott, (Louisville: Westminster John Knox Press, 2004 ), 25. 13 Ibid.
} 
in the midst of this becoming, integrating the creativity and form of the universe. ${ }^{14}$ Such a process of becoming opened the way for the development of process theology and the notion of creatio ex profundis. Keller uses becoming as well as tehom as the basis for her arguments against ex nihilo. In one such argument, she makes a distinction between "origin" and "beginning:" "Tehom is inscribed not before any beginning, not before the beginning, but in it."15 Tehomic language has a type of flowing, as she describes, alongside "beginning," echoing the creative becoming of the universe. Conversely, Keller illustrates "origin" as domineering and controlling over the "beginning" that stems from it. She suggests the difference between origin and beginning "almost" mirrors the difference between creatio ex nihilo and creatio ex profundis, which leads into another argument she raises.

Continuing in her study of becoming and tehom, Keller associates creatio ex nihilo with a dominance model, in which God the Creator is a dominating power: "In theology 'creation' emphasizes an event in relation, and so signifies a 'Creator.' The term therefore comes barnacled with stereotypes of a great supernatural surge of father-power, a world appearing-zapout of the void." ${ }^{\prime 16}$ From such an interpretation of creation as well as creatio ex nihilo's established presence in tradition, Keller argues this dominance model perpetuates the current gendered and dualistic issues in theology. ${ }^{17}$ The dominance model of creatio ex nihilo also sustains a sharp sense of order when attempting to understand creation and the universe. Rejecting a perspective of creative becoming, creatio ex nihilo maintains what she considers a stasis:

\footnotetext{
${ }^{14}$ Ibid, 24, 76.

${ }^{15}$ Keller, The Face of the Deep, 158.

${ }^{16}$ Ibid, 5-6.

${ }^{17}$ I will address Keller's concerns surrounding gender and patriarchy in theology later in my critique of her argument.
} 
But does such nihilism 'originate' in the modern denial of a foundational origin, as is generally supposed — or rather in the doctrine which produces the nihil in the first place?

For as will become evident, that nihil did not 'exist' in the Bible or in its neighboring myths and ideas. The ex nihilo doctrine constructed as orthodoxy itself the pure dualism originating Logos and prevenient Nothing. ${ }^{18}$

Keller holds that dominance model of ex nihilo does not allow a place for tehom and its creative fluidity outside the Logos and the Nothing. Rather, the perpetuation of ex nihilo in creation theology places binding limitations on any potential study and application of tehomic language in addition to any effort made against the accepted doctrine of ex nihilo. In turn, she disputes God's omnipotence and views such an understanding of God as a direct conflict with creatio ex profundis. The belief of God's omnipotence resembles the dualism of ex nihilo that solidifies a boundary between the a-temporal power of God and the worldly creation. Keller encourages a type of panentheism that allows a unity among God, tehom, and creation, once more referring to the creative becoming and form of the universe. Although she raises significant issues concerning the doctrine of creatio ex nihilo, Keller's argument for creatio ex profundis contains its own variation of issues as well, namely her rational against the doctrine of God's divine omnipotence.

\section{Critique of Keller's Argument Against Creatio Ex Nihilo and Divine Omnipotence}

Prior to illustrating my hesitations and remarks concerning several points in her argument, I wish to explore what Keller brings to the current understanding of creation theology, namely her tehomic interpretation of creation and her issue toward the patriarchal and gendered

\footnotetext{
${ }^{18}$ Ibid, 10.
} 
binary in theological discourse. Given the original Hebrew translation, the two opening verses of Genesis explicitly describe a present chaos at the moment of creation, a notion well founded in other belief systems of the ancient world. ${ }^{19}$ Such an explicit mention of tehom in the context of creation should not go unnoticed, which may be the case with creatio ex nihilo. Keller perhaps is too keen to conclude that the lack of tehomic language in the doctrine of ex nihilo is a result of strict boundaries and dominant powers: "Christian orthodoxy originates in a symbolic misogyny in which it cashes in the complex mediations of cosmogony for the property rights of the dominus. ${ }^{20}$ However, she does recognize the minimal focus on tehom within such an interpretation of creation. I view the presence of tehom not so much as a "lack," as she phrases it, but a subtlety. Chaos is still present in creatio ex nihilo, through which the will of God brings forth tehom from nothing. Yet, the subtle presence of tehom in current creation theology may trend towards a minute detail, potentially diminishing its biblical significance. Keller, on the other hand, interprets such an understated inclusion of tehom in ex nihilo as a type of shunning rooted in fear. ${ }^{21}$ To emphasize her point further, she even calls such a fear "tehomophobia.",22 This apparent disregard towards tehomic language in ex nihilo drives Keller to view such a creation theology as an expression of dominion, calling for a creatio ex profundis teaching of creation. While I do not agree with her either/or approach to the notions of ex nihilo and ex profundis, I find Keller's illustration of the tehomic interpretation of Genesis a valuable contribution, if not a necessary reminder, to creation theology.

\footnotetext{
${ }^{19}$ Catherine Keller, On the Mystery: Discerning God in Process, (Minneapolis: Fortress Press, 2008), 47. See also the collection of essays in "Creation in the Biblical Tradition," The Catholic Biblical Quarterly Monography Series 24, ed. Richard J. Clifford and John J. Collins, (Washington D.C.: The Catholic Biblical Association of America, 1992).

${ }^{20}$ Keller, The Face of the Deep, 54.

${ }^{21}$ Ibid, xvi.

${ }^{22}$ Keller devotes a chapter in The Face of the Deep to the distinction between "tehomophobia" and "tehomophilia," $25-40$.
} 
Moving through the theologies of the early church fathers, Keller makes note of what she views as an example of creatio ex nihilo's dominance model through the apparent prevalence of patriarchy and a strict gender binary. The basis of her argument is grounded in the feminine grammar of tehom and the feminine language associated with tehomic imagery and its connection to the theology of becoming. Due to this feminine language, Keller argues the foundation and development ${ }^{23}$ of ex nihilo is rooted in an expression of patriarchy: "Fear of whatever shadows our light, whatever transgresses boundaries, leaks across categories, sneaks out of closets, whatever she-sea might suddenly flood our fragile confidence. Fear of the 'female thing.' Of all things too deep and too fluid: we may call this fear 'tehomophobia." ${ }^{24}$ From what she considers a fear of the feminine chaos rather than a biblical hermeneutic, Keller illustrates a critical portrayal of the patristic development of the doctrine of creatio ex nihilo. Their conceived patriarchal "tehomophobia" continues to perpetuate a gendered model within the current church, one that diminishes the chaos of Genesis. ${ }^{25}$ However, unlike her interpretation of certain church fathers, Keller focuses on St. Augustine's exegetical examination of the creation narrative as well as his focus on the watery depths and other uses of tehomic language. ${ }^{26}$ Although I view her approach to the early development of ex nihilo as bold and generalized, I do find her examination of patriarchal theology and a gendered order within the current church as originating from necessary concerns. Developments in creation theology, whether based upon $e x$ nihilo or ex profundis, should not be limited by gender binaries and other such boundaries.

While her contributions regarding tehomic language and the issue of patriarchy and gendered binaries within creation theology are beneficial, Keller's other arguments stemming

\footnotetext{
${ }^{23}$ Using the works of the patristics, Keller addresses the historical development of the doctrine creatio ex nihilo in the chapter "The fathers' ex nihilo" in The Face of the Deep, 43-64.

${ }^{24}$ Keller, On the Mystery, 58.

${ }^{25}$ Keller, The Face of the Deep, $43-4$.

${ }^{26} \mathrm{Ibid}, 65-6$.
} 
from these main topics are misleading and skeptical. My first concern addresses Keller's relation of creatio ex nihilo and omnipotence, going so far as to view them as mutually inclusive notions. Keller connects the "tehomophobia" to the orthodox notion of God's omnipotence. She states, "In [the fathers'] triumphant logos we have read a logic whereby the creation doctrine guards...unconditional omnipotence against constraining conditions; masculine symbolic privilege against the affective, sensual and unruly feminine..."27 While there are various examples of male dominance in theology throughout history, I question whether omnipotence, in relation to creation theology, should be viewed as patriarchal and an expression of power over the feminine. It seems as though Keller finds creatio ex nihilo and the doctrine of omnipotence mutual due to her interpretation of both notions as misogynist and domineering. If the Creator was understood as omnipotent, then He will exert a model of power rather than a Creator who continually creates from the tehom. According to Keller, omnipotence restricts any creative potential and becoming:

To render the biblically 'all-powerful' deity formally omnipotent was to close out the primal space, the khora or chaos, of creaturely spontaneity. Without that space, human freedom and natural chance are themselves directed by a Lord — who is thereby responsible for the havoc they wreak. ${ }^{28}$

She associates omnipotence with the logic of creatio ex nihilo given the system of dualisms opposing the divine and the created. In other words, Keller understands the all-powerful Creator as against a powerless creation, in which the Creator forces His power on the inferior creation formed out of nothing rather than use the present chaos towards a creative unity. However, I found her connection of creatio ex nihilo and omnipotence unclear, especially viewing the two

\footnotetext{
${ }^{27}$ Ibid, 64 .

${ }^{28}$ Ibid, 49 .
} 
notions as inclusive of each other. The question remains whether a belief in an omnipotent God cannot be held in congruence with a belief in creatio ex profundis. Such a question I hope to examine further in my concluding arguments relating to dependence and power.

Similar to her views concerning omnipotence and creatio ex nihilo, Keller judges the notion of omnipotence as a "dangerously unavowed amorality" due to domineering imposition on creation. ${ }^{29}$ Even further, she holds the belief that an omnipotent God is separate and independent from creatures while, in turn, encouraging a panentheistic relation towards creation brought forth from tehom. ${ }^{30}$ My concern is not necessarily with her support for panentheism, but rather her understanding of omnipotence as an expression of power that necessarily results in a separation between God and creation. What Keller fails to consider is God's omnipotence as revealing His divine transcendence. Kathryn Tanner describes particular views in relation to the agency and transcendence of God. One view illustrates the perspective of Keller in that she contrasts God's transcendence (and omnipotence) against His involvement in creation. Based on this understanding, Tanner provides an idea of the type of relationship between God and the world:

Such talk suggests that God exists alongside the non-divine, that God is limited by what is opposed to it, that God is as finite as the non-divine beings with which it is directed contrasted. A cosmology influenced by such suggestions will characterize a divine agency in the terms appropriate for a finite one. Like that of a finite agent, God's influence will be of a limited sort: it may not extend to everything, it may presuppose what it does not produce, it may require the intervening agencies of others. ${ }^{31}$

\footnotetext{
${ }^{29}$ Ibid.

${ }^{30}$ Ibid, 23.

${ }^{31}$ Kathryn Tanner, God and Creation In Christian Theology: Tyranny or Empowerment?, (Minneapolis: Fortress Press, 2005), 45-6.
} 
Omnipotence is not an example of domineering power or in contrast to God's involvement; rather, it clarifies how God is distinct and not belonging to the finite world. However, this omnipotence and transcendence does not deny an immanent relationship to creation. In my third section, I plan to further expand this examination of omnipotence by arguing that such an understanding of a transcendent and immanent God reveals creation's dependence rather than an example of forceful domineering power.

Keller's position toward an omnipotent God is the basis of another issue within her argument. While examining the biblical narrative of Job, she asserts the notion of omnipotence conflicts with a just God: "If the God of justice is to be counted all-powerful, that God must be held accountable for all injustice...the God in whose name piety blames the victim is the one who caused the suffering. Few theologians... have faced up to this opposition between power and goodness. ${ }^{, 32}$ However, her effort to dissuade others from a belief in an omnipotent God appears disconnected. Continuing with the Job narrative, she uses the whirlwind of God as an illustration of a tehomic creation. Job 38 describes the voice of God crying out from the whirlwind, answering Job's demands to defend Himself. God's answers include various examples of how He is responsible for the diversity of creation, a chaotic display of creativity and complexity, concluding with the monster Leviathan (Job 41). The mention of the sea monster is what Keller uses as the basis for her theodicy question: "Is this the truth of the whirlwind: that God, the 'spirit of the world-wind,' does not will our suffering—-but does will a world, a living, whirling, open-system of a world? That world happens to be this creation...a world of change and interdependence in which suffering is inevitable. ${ }^{, 33}$ I find such a conclusion questionable. It is clear from Keller's description that suffering is always present in

\footnotetext{
${ }^{32}$ Keller, The Face of the Deep, 127.

${ }^{33}$ Keller, On the Mystery, 76.
} 
an ever-changing, chaotic world of creation, a creatio ex profundis. It is also understandable why she would deny the notion of an omnipotent God within such an understanding of the world, in that an all-powerful God is not compatible with a just God for He must be held accountable for the suffering. However, I believe Keller has a misunderstood and false interpretation of omnipotence in relation to God's agency in a suffering world and I intend to demonstrate this claim in my following section.

\section{Explication of Dependence Over Power}

I have outlined Keller's concerns of creatio ex nihilo and the notion of omnipotence as well as provided a simple analysis of key points within her argument. Moving forward, I will address Keller's questionable conclusions and, in doing so, I hope to introduce a contrasting view of omnipotence as revealing creation's dependence on God rather than His dominance and power over it. The first of these conclusions that I find debatable is Keller's relation of creatio ex nihilo and omnipotence as mutual and, thus, equally "tehomophobic" and an affront to the feminine. Instances of patriarchy and misogyny are present in theological history; however, societal influences and human interpretations are more likely at fault rather than the doctrines of ex nihilo and omnipotence. My question relates to these doctrines in the context of creation theology. Referring to the work of H.F. Weiss, May illustrates how ancient Jewish and Christian thought was more concerned with challenges to God's absolute agency in the world rather than questions surrounding the origins of creation: "It is not... a matter of cosmological theory but of a theological affirmation that is forced to use cosmological categories." ${ }^{34}$ The doctrine of creatio ex nihilo was developed to confront the gnostic and philosophical teachings of a dualistic creation, which challenged the beliefs of God's omnipotence. Furthermore, Weiss emphasizes

\footnotetext{
${ }^{34}$ May, 24.
} 
how rabbinic Judaism did not form a specific doctrine of creatio ex nihilo due to the Genesis narrative. The biblical description of creation allowed for an open interpretation of tehom and God's role in the creative process:

The mention of chaos in Genesis 1:1 could also support the view that an external material existed, which God had merely ordered in creating the world. Jewish thought is in its entire essence undogmatic; in the question of the creation of the world it did not find itself tied down by the statements in the Bible and so possessed wide room for manoeuvre for highly variant speculations on creation. ${ }^{35}$

Based on early Jewish and Christian thought, beliefs and doctrines concerning creation theology were developed according to challenges toward divine omnipotence, not solely interpretations of creation. At least according to Jewish belief, perspectives on the tehomic language present in Genesis could vary as long as the omnipotent role of God remained consistent, which suggests the relation between creatio ex nihilo and omnipotence is not necessarily mutual.

Jon Levenson's work on creation theology also supports the perspective that creatio ex nihilo, or in this case creatio ex profundis, and divine omnipotence are not correlative. Although he does not support the doctrine of ex nihilo as an adequate interpretation of the creation narrative, Levenson maintains belief in God's omnipotent role. His reasoning for creatio ex profundis does pertain to divine omnipotence, but not as a necessary mutuality. The doctrine of ex nihilo fails to communicate the "fragility" of created order and the continual "vulnerability" to chaos. ${ }^{36}$ In contrast, the notion of creatio ex profundis illustrates a fluid and dynamic tehom that coexists with creation. Levenson argues, "The point of creation is not the production of matter out of nothing, but rather the emergence of a stable community in a benevolent and life-

\footnotetext{
${ }^{35} \mathrm{Ibid}, 24-5$.

${ }^{36}$ Jon Levenson, Creation and the Persistence of Evil: The Jewish Drama of Divine Omnipotence, (New York: Harper \& Row, 1988), xiii.
} 
sustaining order." ${ }^{37}$ Similar to Weiss' description, Levenson acknowledges early Jewish thought did not hold the two interpretations of creation in a contrasting manner; their focus concerned the restoration of order rather than its method of creation. However, he deviates from such a neutral position and affirms the notion of creatio ex profundis due to the biblical description of God's mastery over tehom, not its elimination. ${ }^{38}$ His divine omnipotence is not an example of domineering power, as Keller claims, but a demonstration of His transcendence and immanence, continually sustaining ordered creation. Even more so, Levenson emphasizes creation's relation toward an omnipotent God: "Whatever the special act of God, in the Hebrew Bible nature is not autonomous and self-sufficient, but dependent upon God's special solicitude, his tender concern for the ordered world." ${ }^{39}$ Regardless of a belief in creatio ex nihilo or ex profundis, creation depends on an omnipotent God through covenantal promises, not forcibly restrained through domineering power.

Following the question of a necessary correlation between creatio ex nihilo and divine omnipotence, I wish to challenge Keller's definition and subsequent conclusion of omnipotence as an example of dominance and power. She views such a doctrine of dominance rising from a fear of tehom, as though the chaotic waters of creation require absolute control. I find Keller does not have a proper definition of power within the notion of omnipotence. The type of power as understood in omnipotence is not one of dominance and blind control. Rather, omnipotence is viewed as self-sufficient power through which God expresses His will. ${ }^{40}$ One notable example of God's self-sufficient power, given the context of this argument, is creation. Not as an exercise in force, but a free act of will. Although he has a different interpretation of the word power,

\footnotetext{
${ }^{37}$ Ibid, 12.

${ }^{38}$ Ibid, 26-7.

${ }^{39}$ Ibid, 12.

${ }^{40}$ Summa Theologica I.25.1.
} 
Rowan Williams does articulate how creation is not a result of domineering force, but is of God's will:

But what creation emphatically isn't is any kind of imposition or manipulation: it is not God imposing on us divinely willed roles rather than the ones we 'naturally' might have, or defining us out of our own systems into God's. Creation affirms that to be here at all, to be part of this natural order and to be the sort of thing capable of being named —or of having a role_-is 'of God;' it is because God wants it so. ${ }^{41}$

Creation is the affirmation of God's omnipotent role, independent from a specific interpretation of the Genesis narrative. The notion of creation is not an explanation or varying perspective of either the nothingness or watery chaos. Rather, as Williams illustrates, it is a statement: “[Creation]...exists as a real situation because of God's reality, as it were, turned away from God to generate what is not God...a statement that everything depends on the action of God." "42 The focus of omnipotence in the context of creation is not about enforcing a controlling power; instead, it is about the created world being dependent on God for order and a benevolent relationship.

Questions regarding the notion of omnipotence, interpreted either as domineering or selfsufficient power, raise other secondary issues, specifically related to God's transcendence and immanence. $^{43}$ If one were to accept Keller's definition of power, divine omnipotence would imply a transcendental God that is absent at best, or oppressive at worst. However, the notion of omnipotence does not necessarily suggest a strict dualism between God and creation, representing this sharp divide that does not allow for a loving relationship. Rather, divine

\footnotetext{
${ }^{41}$ Rowan Williams, On Christian Theology, (Malden: Blackwell Publishers, 2000), 69.

42 Ibid, 68.

${ }^{43}$ Robinette, 532.
} 
omnipotence expresses creation's dependence on a self-sufficient God and, as Tanner argues, illustrates a free communication of intimacy and regard:

A self-determined transcendence does not limit God's relation with the world to one of distance. A radical transcendence does not exclude God's positive fellowship with the world or presence within it. Only created beings, which remain themselves over and against others, risk the distinctness of their own natures by entering into intimate relations with another. God's transcendence alone is one that may be properly exercised in the radical immanence by which God is said to be nearer to us than we are to ourselves. ${ }^{44}$ Tanner notes any sense of distinction and isolation is through the action of the created, not the Creator, for such a separation from God is a result of denying one's created nature. Given this understanding between God and His creation, this overarching question of power should not be directed towards the notion of omnipotence or God's transcendent nature. Rather, such a question should be raised with respect to creation's interpretation of and response to God's immanent presence and continual offering of benevolence. The perception of a domineering or self-sufficient power is the fault of creation's interpretation. Rather, creation must freely acknowledge its dependence on God and recognize His radical nearness: "Since the entirety of created being is conferred by divine agency, created beings have no domain of operations independent of God's agency." ${ }^{45}$ Without such recognition of dependency, creation denies a complete, intimate relationship with God. This rejection of a present relationship with God creates the sense of separation that Keller claims is the fault of an omnipotent God and, thus, creates a misunderstanding of power in relation to God's transcendent nature.

\footnotetext{
${ }^{44}$ Kathryn Tanner, God and Creation In Christian Theology: Tyranny or Empowerment? (Minneapolis: Fortress Press, 2005), 79.

${ }^{45}$ Ibid, 95.
} 
After addressing the relation and agency of omnipotence with regard to creation, I offer a final challenge to a more implicit issue found in Keller's argument. She touches upon the remaining question of the problem of evil throughout her work, while not providing a full examination of the issue. Her chapter on the biblical narrative of Job is the closest she comes to fully taking on the problem of evil. As I mentioned in my previous section, Keller finds conflict between the notion of omnipotence and a just God, meaning an omnipotent God of justice must be held accountable for the presence of suffering and evil in the created world. ${ }^{46}$ She cites the cries of Job in order to support her position and uses the description of the answering whirlwind as evidence for creatio ex profundis. The experience of suffering is considered inevitable in a changing, tehomic world. ${ }^{47}$ However, Keller's understanding of evil's presence is based upon her definition of omnipotence, which I disputed previously as a false interpretation of power. Similar to Keller, John Caputo argues against the notion of omnipotence in light of the presence of suffering; yet, he does so from a different angle. His position is grounded in the belief of a weak God rather than a powerful one: "The name of God is the name of our hope in something unconditional but without sovereign power...the name of God is the name of a promise, a weak force, not a worldly power. ${ }^{, 48}$ Referring to a common challenge towards God, Caputo exclaims the concept of an all-powerful God conflicts with His apparently varying involvement in the world's suffering. Instead, Caputo believes the name of God is a stronger force against suffering and the goodness of creation as a validation of His "yes."49 While I agree with his mention of human fault as part of the problem of evil, I take issue with Caputo's understanding of

\footnotetext{
${ }^{46}$ Keller, The Face of the Deep, 127.

${ }^{47}$ Keller, On the Mystery, 76.

${ }^{48}$ John Caputo, The Weakness of God: A Theology of the Event, (Indianapolis: Indiana University Press, 2006), 90.

${ }^{49}$ Ibid, 91.
} 
omnipotence and promotion of a "weak" God in the context of suffering. This portrayal of omnipotence is not the answer to evil, but weakness is not the resolution either.

Levenson offers a third perspective, one based in eschatological promise: "The central affirmation of apocalyptic is that the evil that occurs in history is symptomatic of a larger suprahistorical disequilibrium that requires, indeed invites, a suprehistorical correction. As evil did not originate with history, neither will it disappear altogether in history, but rather beyond it, at the inauguration of the coming world." ${ }^{, 50}$ While evil and suffering will persist in temporal history, God will demonstrate mastery over the new creation of the future just as He mastered the tehomic waters described in Genesis. He does not simply eradicate evil during the process of creation; rather, as Levenson argues, God enacts creative order and establishes covenantal promises with the created world. Through these promises, creation is able to "cope" with evil and recognize the sovereignty of God. Even further, Levenson states, "It is through obedience to the directives of the divine master that his good world comes into existence." ${ }^{, 51}$ Obeying and maintaining the promise established between Creator and created allows the world to persevere against evil, even with evidence to renounce such a promise. The incomprehensibility of an omnipotent God who expresses unconditional benevolence towards His creation sustains the order and goodness of the world, providing eschatological hope for the new creation. ${ }^{52}$

\section{Conclusion}

While Keller's challenges to the standard views and interpretations of current creation theology are helpful, and perhaps even necessary, I felt that her argument overall lacked persuasive evidence to accept the notion of creatio ex profundis in place of ex nihilo as well as to

\footnotetext{
${ }^{50}$ Levenson, 50 .

${ }^{51}$ Ibid, 127.

52 Ibid, 156.
} 
deny the existence of a omnipotent God. That is to say, I did not find fault with the notion of ex profundis in of itself. It is a valid interpretation of the creation narrative in Genesis. However, I did not agree with Keller's stance to view ex profundis as the only proper interpretation of Genesis. The two creation theologies are credible in their own creative light. As Levenson described, the method of how creation came into existence is less important when compared to the Creator bringing forth order and promise to His creation. Conversely, Keller's refutation of divine omnipotence is more serious and potentially detrimental. The God of biblical and church tradition is omnipotent and immutable. Accordingly, the views put forth by Keller and Caputo, panentheism and "a weak God" respectively, are unorthodox and in direct conflict with the understanding of the divine God. The perspectives of panentheism and a weak God may not be fully unorthodox in of themselves, but rather become such dissenting views when they are meant to replace accepted doctrines of God's image. In my examination of her argument, I sensed most of Keller's disagreement and assertions were due to her misinterpretation of power as a domineering force rather than a self-sufficient agency. If her understanding of God's power were revised, then perhaps most of her challenges to creation theology and divine omnipotence would be more easily grasped and acceptable within the current understandings of creation theology. 


\section{Bibliography}

Caputo, John D. The Weakness of God: A Theology of Event. Bloomington: Indiana University Press, 2006.

Copan, Paul and William Lane Craig. Creation Out of Nothing: A Biblical, Philosophical, and Scientific Exploration. New York: Baker Academic, 2004.

Copan, Paul. "Is Creatio Ex Nihilo A Post-Bibilical Invention? An Examination of Gerhard May’s Proposal." Trinity Journal 17.1 (Spring 1996): 77-93.

Faber, Roland. God as Poet of the World: Exploring Process Theologies. Trans. Douglas W. Scott. Louisville: Westminster John Know Press, 2004.

Gunton, Colin E. The Triune Creator: A Historical and Systematic Study. Grand Rapids: Eerdmans, 1998.

Keller, Catherine. "'Be This Fish': A Theology of Creation out of Chaos." Word \& World 32.1 (Winter 2012): 1520.

Keller, Catherine. On the Mystery: Discerning Divinity in Process. Minneapolis: Fortress Press, 2008.

Keller, Catherine. Face of the Deep: A Theology of Becoming. New York: Routledge, 2003.

Levenson, Jon Douglas. Creation and the Persistence of Evil: the Jewish Drama of Divine Omnipotence. San Francisco: Harper \& Row, 1988.

May, Gerhard. Creatio ex nihilo: The Doctrine of 'Creation Out of Nothing' in Early Christian Thought. Edinburgh: T\&T Clark, 1994.

Robinette, Brian. “The Difference Nothing Makes: Creatio Ex Nihilo, Resurrection, and Divine Gratuity." Theological Studies 72 (2011): 525-557.

Tanner, Kathryn. God and Creation in Christian Theology: Tyranny or Empowerment?. Minneapolis: Fortress Press, 1988.

Williams, Rowan. On Christian Theology. Malden: Blackwell Publishers, 2000. 